\title{
The Status of Access to Effective Remedies by Victims of Human Rights Violations Committed by Multinational Corporations in the African Union Member States
}

Jean Pierre Mujyambere*

DOI: $10.21827 / 5 \mathrm{a} 6 \mathrm{afa} 2873631$

\begin{abstract}
The main purpose of this paper is to document the failure and dysfunction of the existing judicial structures of many African Union's Member States (AUMS), to address human rights violations that are often committed by Multinational Corporations (MNCs) on their territories. Concretely, it assesses the access of victims of the MNCs' human rights abuses (in the AUMS) to effective remedies and the obstacles they face through a number of case studies. Although these victims' cases are specific to some countries, they illustrate a general challenge faced by victims of such abuses from many AUMSs. The examination of these cases, in turn, results in the examination of the legal remedies the victims use and the obstacles they face in the pursuit of such remedies, either in their domestic jurisdictions or in other foreign national jurisdictions. The present paper also weighs the obstacles faced by the same victims in their quest for effective remedies against the concept of "African solutions to the problems of Africa." Finally, it is suggested that the reluctance of the AUMSs to hold MNCs accountable for their human rights violations, which are often committed on their territories, and the non-redress of the same violations by other forums outside the African continent, places the onus on African regional and sub-regional mechanisms of human rights protection to get involved.
\end{abstract}

\section{Introduction}

The access to an effective remedy for victims of human rights violations is an internationally recognised right guaranteed under international and regional human rights law. For instance, at the international level, this right is provided for under Article 8 of the Universal Declaration of Human Rights, ${ }^{1}$ as well as Article 2(3)(a) and (b) of the International Covenant on Civil and Political Rights. ${ }^{2}$ In Europe, the same right is provided for under Article 13 of the European Convention on Human Rights, as well as by Article 14 of the European Charter of Fundamental Rights ${ }^{3}$. At the African Union (AU) level, although the African Charter on Human and People's Rights (African Charter) does not have a specific provision of that kind, its Article 1 obliges Member States to respect and enforce the rights enshrined therein. Moreover, its Article 7(1) provides that 'every individual shall have the

LLM in International and Public European Law from Erasmus University of Rotterdam, Advanced Master in Human Rights from the Leuven Academy in Belgium.

1 UN General Assembly, Universal Declaration of Human Rights, 10 December 1948, (183rd plenary meeting) $\mathrm{A} / \mathrm{RES} / 3 / 217 \mathrm{~A}$.

2 UN General Assembly, International Covenant on Civil and Political Rights, (1976) 999 UNTS 407 (ICCPR).

3 Council of Europe, European Convention for the Protection of Human Rights and Fundamental

Freedoms, as amended by Protocols Nos 11 and 14 (1950) ETS 5 (ECHR). 
right to have his cause heard, including a right to an appeal to competent national organs against acts of violating his fundamental rights as recognised and guaranteed by convictions, laws, regulations and customs in force'. In its decisions, the African Commission on Human and People's Rights (ACHPR) has repeatedly interpreted Article 7(1) of the African Charter to include the right of access to an effective remedy. ${ }^{5}$

More specifically, when MNCs are accused of being involved in human rights abuses, the UN Guiding Principles on Business and Human Rights (UNGP) require states to take appropriate measures to ensure the access to effective remedies for victims. ${ }^{6}$ Under this obligation states are also required to investigate, to punish the perpetrators, and to repair the damage suffered by the victims. The UNGPs also require MNCs to play an active role in the remediation of the victims' damages either themselves or by co-operating with the authorities for that purpose. ${ }^{7}$

Despite the existence of such obligations imposed on the African Union Member States (AUMSs) and Multinational Corporations (MNCs), nowadays, the lack of redress regarding human rights abuses committed by MNCs in the AUMSs has become a major concern. There are many MNCs that stand accused of involvement in human rights abuses and yet their victims still face many barriers to access effective remedies in domestic jurisdictions. ${ }^{8}$ The same cases are often also brought before the MNCs home jurisdictions or in other foreign domestic jurisdiction, yet all efforts appear to be without success.

The present paper discusses the problems regarding the access to effective remedies by victims of the MNCs human rights abuses in three main sections. The first section provides a general background to this question within the AUMSs. The second discusses cases that expose the barriers victims face in their quest for remedies, either in domestic jurisdictions or before the MNCs home jurisdictions, as well as in other foreign domestic fora. The third section examines how the lack of access to effective remedies for victims from AUMSs in domestic jurisdictions constitutes a challenge to the concept of 'African solutions to the problems of Africa.' The conclusion summarises the main points discussed in each section.

\section{Background: MNCs' Human Rights Abuses in the AUMSs}

\section{A. Why African Countries Remain a Favourite Destination for MNCs Today}

For several reasons, the African continent has been perceived as a risky destination for MNCs. These include, for example, insecurity, weak democracies, poor governance, as well as poor economic regulatory policies, all of which prevail in many AUMSs. ${ }^{9}$ However, to

African Union, African Charter on Human and People's Rights, (1986) UNTS 218.

African Commission, Krishna Achuthan (on behalf of Aleke Banda), Amnesty International (on behalf of Orton and Vera Chirwa), Amnesty International (on behalf of Orton and Vera Chirwa) v Malawi, Communications 64/9268/92- 78/92_8AR, para 12, at <achpr.org/communications/decision/64.92-68.92-78.92_8ar/>, (accessed 19 November 2017).

6 United Nations, Guiding Principles on Business and Human Rights, Implementing the United Nations "Protect, Respect and Remedy" Framework, Geneva and New York, 2011, 27-31.

7 Id, 31-33.

8 Aguirre, D, "Corporate social responsibility and human rights law in Africa" 5(2) African Human Rights Law Journal (2005), at <ahrlj.up.ac.za/aguirre-d> (accessed 19 November 2017).

9 Africa Progress Panel, "Despite steady improvement, corruption remains a concern", at $<$ africaprogresspanel.org/governance-and-transparency/?gclid=EAIaIQobChMI5-

jbg7T81QIVExMbCh3C4AUIEAAYAiAAEgLkEvD_BwE>, (accessed 19 November 2017). 
this date it is remarkable that the African countries remain a favourite destination for MNCs of varying nations. The term MNC itself in this paper refers to "a legal person that owns or controls production, distribution or service facilities outside the country in which it is based" ${ }^{10}$ while the term MNCs' accountability refers to the legal responsibility of MNCs visà-vis their obligation to respect human rights under national legislations and international and regional human rights law. ${ }^{11}$

There are many reasons that render the AUMSs attractive to MNCs. First, the AUMSs are "resource-rich." 12 According to the Business and Human Rights Resource Centre (BHRRC), the current MNC investments that are booming in the AUMSs are linked to continuous discoveries of oil, gas and minerals sites as well as new prospects in agriculture in the AUMS. ${ }^{13}$ As stated by the Institute of the West-Asia and African Studies of the Chinese Academy of Social Sciences, 'African countries contain more than half of the world resources of cobalt, manganese, gold and significant supplies of platinum, uranium and oil. ${ }^{14}$ According to scholars like Chella, the natural resources from the AUMSs generate billions of dollars in the extractive industries. ${ }^{15}$ In other words, MNCs are mostly attracted to the natural resources that the African continent abounds. Moreover, unlike a number of other continents, Africa records a high rate of population growth, a fact which has a direct correlation with a cheap workforce likely to sustain activities of these MNCs across the African continent as well as a consumer market growth. ${ }^{16}$ In addition, most of these MNCs which invest in the AUMSs are often subjected to fewer regulatory constraints or are accorded many concessions for purposes of attracting them. ${ }^{17}$

10 Jagers, N, Corporate human right obligations: In search of accountability, (School of Human Rights research 2002) 11.

11 Cernic, J L, Human rights Law and Business: Corporate Responsibility for fundamental Human Rights (Europa Law Publishing 2010) 14.

12 International Monetary Fund, Lundgren, C J et al., Boom, Bust, or Prosperity? Managing Sub-Saharan Africa's Natural Resource Wealth, 2013, 4-8, at <imf.org/external/pubs/ft/dp/2013/dp1302.pdf> (accessed 19 November 2017).

13 Business and Human Rights Resource Center (BHRRC), Business and human rights in Africa: Time for a responsibility revolution. A regional overview, September 2014, 2-3, at $<\mathrm{https} / / /$ businesshumanrights.org/sites/default/files/documents/Time-for-responsibility-revolution-business-human-rightsAfrica-Sep-2014_1.pdf > (accessed 2 November 2017).

14 The institute of West-Asia and Africa Studies of the Chinese Academy of Social Sciences and John Kennedy School of Government, Harvard University, Forstater, $\mathrm{M}$ et al., Corporate responsibility in African Development, October 2010, 9, at <sites.hks.harvard.edu/m-rcbg/CSRI/publications/workingpaper_ 60.pdf $>$, (accessed 19 November 2017).

15 Jessie, C, The complicity of the Multinational Corporations in international Crimes: An examination of principles (Bond University 2012) 11.

16 Blackston, S K et al., Game on: private equity and investment in Africa, A discussion with the US private equity executives on some of the newest opportunities in emerging markets, PWC, March 2014, 8, at $<$ pwcavocats.com/fr/assets/files/pdf/2014/05/investment-in-africa.pdf> (accessed 19 November 2017).

17 Ibid. 


\section{B. MNCs and Human Rights Abuses in the AUMSs}

It is comprehensible that the activities of MNCs are needed in the AUMSs because they contribute to the development of their economies, create more jobs, bring new technologies, and contribute to building new and modern infrastructures across these countries. ${ }^{18}$ On the other hand, there are many controversies on how these MNCs fail to respect human rights in the AUMSs. In pursuit of their economic interests, a large number of MNCs operating in the AUMS are currently accused of being involved in human rights abuses. ${ }^{19}$ Some of them are even alleged to be implicated in war crimes and crimes against humanity as well as supporting repressive regimes in many AUMS. ${ }^{20}$ For example, reports from various human rights organisations have alleged implications of more than $80 \mathrm{MNCs}$, from developed and developing countries, in the illegal exploitation of natural resources, forced labour, and distribution of weapons to different armed groups in the current conflicts in the Democratic Republic of Congo (DRC). ${ }^{21}$ A prime example is the AngloGold Ashanti mining company from South Africa which was accused of buying weapons and funding criminal activities of different rebel movements during the ethnic conflicts in the Ituri region in Eastern DRC. ${ }^{22}$

As argued by Kremnitzer, MNCs enjoy much more economic and political influence than their host states as they retain "limitless capacities to do well and to cause harm." ${ }^{23}$ This is the case in many AUMSs where MNCs use their economic powers to control, not only their economies, but also other key sectors including politics and justice systems. ${ }^{24}$ In other words, the economic vulnerability of many AUMS renders them vulnerable vis-a-vis MNCs, a fact that has a negative impact on human rights and in particular on the right to access effective remedies by victims of MNCs. The power influence of MNCs weighs more on AUMS because these countries are still facing challenges such as extreme poverty, poor governance, corruption, inefficiency of their judicial systems, and armed conflict.

According to Mnyongani, nowadays, MNCs have become strategic in their approaches because they prefer to invest in countries whose human rights records are poor. ${ }^{25}$ This also means that the AUMS' desperate need for investments constitutes another fact that renders them vulnerable vis-à-vis MNCs. To attract MNCs to their countries, most AUMSs accord concessions, in terms of compliance with human rights standards, to MNCs in their investment agreements. The same fact also explains why many AUMS often try to cover or hide human rights abuses that are committed by MNCs on their territories ${ }^{26}$ or co-operate

18 Giuliani, E, Multinational Corporations' Economic and human rights impacts on developing countries: A review and research agenda, University of Pisa, Italy, (2013), 7, at <ec.unipi.it/documents/Ricerca/papers/2013158.pdf> (accessed 19 November 2017).

19 Aguirre, supra nt 8, pp. 2-3.

20 Mugambi, L, Multi-National Corporations in Human Rights Protection and the Role of the African Union, 7 August 2014, 4, at <ssrn.com/abstract $=2477261>$ (accessed 19 November 2017).

21 Gotzman, N, Legal personality of the corporation and International Criminal Law: Globalization, corporates human rights abuses and the Rome Statute, (The University of Queensland, Australia 2008) 39.

22 Jessie, supra $n t, 15$.

23 Kremnitzer, M, "A possible case for imposing criminal liability on Corporations in International Law", 910 Journal of International Criminal Justice (2010), at <corteidh.or.cr/tablas/r26652.pdf> (accessed 19 November 2017).

24 Chukwuemeka, E, "African Underdevelopment and the Multinationals - A Political Commentary", 4(4) Journal of Sustainable Development (2011) 104.

25 Mnyongani, F D, Accountability of Multinational Corporations for human rights violations under international law (PhD thesis, University of South Africa, 2016) 31.

26 Jessie, supra $n t 15,13$. 
with them in their perpetration. ${ }^{27}$ By investing in such countries, these MNCs are aware that in case they abuse human rights their hosts will be unable or unwilling to hold them accountable for their wrongdoing in national jurisdictions. Although every AUMS is free to design its own legal framework in order to attract as many MNCs as possible to its territory, such legal framework has to comply with the international human rights instruments to which it is a party. More practically, the bilateral agreements between AUMSs and MNCs should be designed in such a way as to guarantee the right of access to effective remedies for those whose human rights are affected by the activities of the MNC in question.

\section{Cases of MNC's Human Rights Abuses in the AU MS: The Elusive Quest for Remedies by Victims}

In case of human rights violations, international law requires that the perpetrators be brought to justice, regardless of whether they are natural or legal persons, such as MNCs. ${ }^{28}$ The victims' rights to access effective remedies in case of human rights abuses is also provided for under various national constitutions, procedurals rules, and regulations in different countries including those of the African Union. These human rights instruments, regulations, and national legislations require states to investigate and to punish the perpetrators and to repair the damages suffered by victims in case of any human rights abuse. As mentioned earlier in the introduction of this paper, the UNGPs also require MNCs to play an active role in the promotion and the protection of the victims' right to access effective remedies in cases where they are implicated in human rights abuses.

Despite the existence of such obligation imposed upon the AUMSs and MNCs, nowadays, the lack of access to effective remedies for victims of the MNCs' human rights abuses from the AUMSs has become a major concern. Today, there are many MNCs operating in the AUMSs that stand accused of involvement in human rights abuses while their victims face many barriers to access effective remedies in domestic jurisdictions. ${ }^{29}$ The same cases are often also brought before the MNCs' home jurisdictions or in other foreign domestic fora but without success.

For further exploration of this topic, three cases were selected to illustrate the complex challenges that victims of such abuses face in their quest for remedies. These cases shed light on the inefficiency of the justice systems in AUMSs vis-à-vis human rights abuses committed by MNCs. They highlight how MNCs undermine the victims' right to access effective remedies within domestic jurisdictions and in jurisdictions outside the AUMS as well as the conflict of interests that AUMS' governments are often confronted with. Finally, these cases illustrate a general challenge that these victims face which warrants the establishment of African regional or sub-regional solutions. In concrete the examination of these cases focuses on the three following points: 1) the nature of violations in terms of what happened and the role played by an MNC in the perpetration of the alleged human rights abuses; 2) the types of remedies pursued by victims and where those remedies were pursued; 3) the obstacles faced by victims in pursuit of said legal remedies, either in domestic courts

\footnotetext{
27 Tsafack, J B F, In research for direct corporate responsibility for human rights violations in Africa: Which way forward, (University of Pretoria, South Afria 2004) 2.

28 Amnesty International, Injustice Incorporated, Corporate abuse and the human rights to remedy 2014, 11, at <amnesty.org/download/Documents/8000/pol300012014en.pdf> (accessed 19 November 2017).

29 Aguirre, supra nt 8, 3.
} 
or before the MNCs' home courts as well as in other foreign domestic jurisdictions outside the African continent.

\section{A. The Anvil Mining's Case of the DRC \\ i. Introduction}

Anvil Mining Ltd. is a MNC from Canada. When the alleged violations of this case were committed, Anvil Mining maintained another main headquarters in Australia. ${ }^{30}$ On the African continent, Anvil Mining is mostly engaged in mining operations in the DRC and in its neighbouring country of Zambia. ${ }^{31}$ The incident at the centre of this case took place in Kilwa town at the Dikulushi Copper and Silver mining extraction site on the $14^{\text {th }}$ October 2004. Anvil Mining had been operating in this region since 2000. ${ }^{32}$ The Kilwa town was a strategic point for Anvil Mining's operations due to its location near the Lake Moëro port. The company used this port to facilitate all its operations in the former Katanga province in the South-East region of the DRC. ${ }^{33}$ According to the latest provincial reforms, the town of Kilwa is now situated in the province of Haut-Katanga. ${ }^{34}$

The Anvil Mining case illustrates the barriers that victims of human rights abuses face due to the dysfunction, irregularities and political interference within domestic justice systems. It also exhibits the reluctance of the MNCs' home courts, along with other foreign domestic jurisdictions, to address human rights abuses committed by MNCs in the AUMSs.

\section{ii. A Brief Description of the Facts}

The facts around the involvement of Anvil Mining in human rights abuses in Kilwa were internationally revealed in a report of the United Nations Mission (MONUSCO) in the DRC. ${ }^{35}$ The same facts were also exposed by reports from human rights organisations such as CIDH (Action Contre l'Impunité des Violations des Droits de l'Homme - based in Lubumbashi), ASADHO (Association Africaine de Défense des droits de l'Homme -based in Kinshasa), and RAID (Rights and Accountability - based in the UK) of September 2005. ${ }^{36}$ These three organisations monitor the impacts of the activities of MNCs on human rights in the DRC.

According to the MONUSCO report, on the $14^{\text {th }}$ October 2004 a small group of 'six or seven persons', who were poorly armed and organised, claimed to belong to the Revolutionary Movement of the Liberation of Katanga, occupied the mining town and the port of Kilwa. ${ }^{37}$ In response to that insurgency, with the logistic support of Anvil Mining, the

30 Adam, M, "Crushed by an Anvil: A case study of Responsibility for Human Rights in the Extractive Sector", 11(1) Yale Human Rights and Development Journal (2014) 4.

31 Ibid.

$32 \quad I d, 5$.

33 Canadian Center for International Justice (CCIJ), "Backgrounder: The case against Anvil Mining", 1, at $<$ https://www.ccij.ca/content/uploads/2015/07/Anvil-backgrounder-FINAL-EN.pdf> (accessed 6 November 2017).

34 The Organic Law No. 15/006 of 25 March 2015 establishing the news boundaries of the provinces and those of the city of Kinshasa (2015).

35 United Nations Missions in the Democratic Republic of Congo (MONUSCO), Report on the Conclusions of the special investigation concerning allegations of Summary executions and other Human rights violations perpetrated by armed forces of the Democratic Republic of Congo (FARDC) in Kilwa, Katanga Province of October 15, 2004, 23 September 2005 at <raid-uk.org/sites/default/files/monuc-final-report.pdf> (accessed 19 November 2017).

36 ACIDH, ASADHO and RAID, Joint report on Kilwa: Anvil Mining Limited and the Kilwa Incident: Unanswered Questions, October 2005, at <raid-uk.org/sites/default/files/qq-anvil.pdf> (accessed 19 November 2017).

37 MONUSCO Report, supra nt 35, 1. 
DRC's soldiers committed many human rights violations. These abuses included the killing of more than 100 civilians, $^{38}$ torture, rape, widespread looting, extortions of civilians' properties and arbitrary detentions. ${ }^{39}$ Many reports on the incident claimed that Anvil Mining's vehicles were used in the transportation of looted property as well as the transport of corpses to mass graves. ${ }^{40}$ The same reports also alleged that Anvil Mining's aeroplanes were used in the transfer of arrested civilians from Kilwa to Lubumbashi (the capital city of the Katanga province). ${ }^{41}$ Additionally, during an interview with Anvil Mining's representative by the MONUSCO investigators, he acknowledged having provided vehicles, drivers, aeroplanes, food rations and the payment of salaries to the DRC's military forces. ${ }^{42}$ In brief, the facts of this case prove that it is unquestionable that Anvil Mining bears great responsibility for the human rights abuses committed in Kilwa on $14^{\text {th }}$ October 2004. In legal terms, Anvil Mining acted in complicity with the DRC soldiers in the commission of human rights violations in Kilwa. Its responsibility stems from the fact that this company facilitated the perpetration of such abuses by DRC soldiers.

\section{iii. The Victims' Endeavours to Access Effective Remedies}

After the publication of various reports on the Kilwa incident, the international community exerted pressure on the DRC's government, requesting it to bring to justice those presumed to be implicated in human rights abuses in Kilwa. In collaboration with victims, the Prosecutor of the Military Court of Lubumbashi opened an investigation. ${ }^{43}$ This investigation was completed in October 2006 and has led to charges against nine government soldiers for war crimes, arbitrary arrest and detention, as well as torture and murder. ${ }^{44}$ Three employees of Anvil Mining were also accused of aiding and abetting the government's soldiers in the perpetration of the above-mentioned violations. ${ }^{45}$ On 28 June 2007, the Lubumbashi military court dismissed these accusations by concluding that what happened in Kilwa was simply the 'incidental results of the fighting' and therefore acquitted all the accused. Likewise, Anvil Mining, which was not formally accused before the court, was also cleared of any charge in relation to this case. ${ }^{46}$

In collaboration with victims, the Prosecutor appealed against that decision but in vain. In its decision of December 2007, the military high court of Lubumbashi declared that the victims' claims against Anvil Mining would not be examined in the appeal, therefore,

$38 I d, 6$.

39 Kyriakakis, J, "Australian Prosecution of Corporations for international Crimes, The Potential of the Common Wealth Criminal Code" 5 Journal of International Criminal Justice (2017) 813.

40 ACIDH and RAID, Kilwa: A year after the massacre of October 2004, a joint report of October 2005 , 6 at <https://www.oecdwatch.org/cases/Case_82-en/625/at.../fil > (accessed 6 November 2017).

41 Ibid.

42 MONUSCO report, supra nt 35, 8.

$43 I d, 11$.

44 Global witness, RAID, ACIDHP, ASADHO/ KANTANGA, Kilwa Trial: A denial of justice, a chronology October 2004 - October 2007, 8, at <https://reliefweb.int/sites/reliefweb.int/files/resources/569D040 ADAA80E0A8525731B0072DC2E-Full_Report.pdf $>$ (accessed 6 November 2017)

45 Id, 9.

46 BHRRC, Anvil Mining lawsuit (re Dem. Rep. of Congo), at <business-humanrights.org/en/anvil-mininglawsuit-re-dem-rep-of-congo> (accessed 19 November 2017). 
restricting that request to the cases examined by the lower court. ${ }^{47}$ In other words, the Military and the High Military Courts of Lubumbashi declared the accusations against Anvil Mining to be inadmissible without any clear legal ground. For the retained charges, the appellate court merely confirmed the decision of the lower court and therefore acquitted all of the accused, including three employees of Anvil Mining. ${ }^{48}$ Since Anvil Mining had other main offices in Australia during the Kilwa incident, the Australian Federal Police (AFP) opened an investigation into the company in September $2004 .{ }^{49}$ However, this investigation was closed after the case was rejected by the DRC's courts. ${ }^{50}$ Moreover, as Anvil Mining was from Canada, victims brought their cases before the Canadian courts, without success. With the assistance of the Canadian Association against Impunity (CAAI), victims of these abuses filed their complaints in the Superior Court of Quebec in November $2010 .^{51}$ In its first decision of April 2011, the Court declared itself to be competent to adjudicate the case. ${ }^{52}$ The Judge found that the case's rejection in Canada would result in the denial of the victims' right of access to an effective remedy. ${ }^{53}$ In fact, the possibility for this case to be heard in other domestic fora was exhausted. However, on 25 January 2012, this decision was unfortunately reversed by the Appellate Court on the ground that the Canadian courts are not competent to rule on this case because victims failed to prove their impossibility to access a remedy in other fora. ${ }^{54}$ Victims and their supporters appealed against this decision before the Supreme Court but in vain. In its decision of November 2012, the Canadian Supreme Court declared that 'it would not hear the plaintiffs' appeal. ${ }^{55}$

\section{iv. Obstacles Faced by Victims in the Pursuit of Remedies}

The major obstacles faced by victims in domestic courts include first of all dysfunctions and irregularities within the DRC's justice system. According to different external observers, the trials of this case before the DRC's courts were characterised by a lack of independence and transparency, significant barriers in lawyer's access to victims, and lack of co-operation with the military authorities. ${ }^{56}$ Secondly, various awareness campaigns for victims and local leaders were conducted by the government authorities and military officials, requesting them to drop their accusations against Anvil Mining on the grounds that this company had contributed much to their well-being. ${ }^{57}$ The MONUSCO report also alleged that government

47 Global Witness, Military Court of Appeal succumbs to political interference in Kilwa Trial in 21 December 2007,21 December 2007, at <globalwitness.org/en/archive/military-court-appeal-succumbs-political-interferencekilwa-trial/> (accessed 19 November 2017).

BHRC, Anvil Mining lawsuit (re Dem. Rep. of Congo), supra nt 46.

Kyriakakis, supra nt 39, 811-812.

50 BHRRC, Anvil Mining lawsuit (re Dem. Rep. of Congo), supra nt, 46.

51 Lee, R, Anvil wins latest round in Congo massacre case, Open Society Initiative for Southern Africa (OSISA), February 2012, at <osisa.org/economic-justice/drc/anvil-wins-latest-round-congo-massacre-case> (accessed 19 November 2017).

52 Cameron, A, Hughes, N, "Mining in the Courts", 3 Year in Review (2015) 15, at $<$ mccarthy.ca/pubs/Mining\%20in\%20the\%20Courts\%202013.pdf> (accessed 19 November 2017).

53 Meeran, R, "Tort Litigation against Multinational Corporations for Violation of Human Rights: An overview of the position outside the United States", 5 City University of Hong Kong Law Review (2011) 12.

54 Ibid.

55 BHRRC, Anvil Mining lawsuit (re Dem. Rep. of Congo), supra nt 46.

56 De Schutter, $\mathrm{O}$ et al., The Third Pillar: Access to judicial remedies for human rights violations by Transnational Business, December 2013, at <corporatejustice.org/documents/publications/eccj/the_third_pillar_access_to_judicial_remedies_for_human_rights_violation.-1-2.pdf> (accessed 19 November 2017) 111-112.

57 MONUSCO Report, supra nt 35, 11. 
authorities had pressured local human rights organisations to give up their support to victims in their quest for justice against Anvil Mining. ${ }^{58}$ The third major obstacle faced by victims before the DRC's courts was the political interference in the justice system. During the trial before the Military Court, the government authorities pressured the prosecutor, who had collaborated actively with victims, to drop the charges against Anvil Mining and its three employees. ${ }^{59}$ When trying to resist, he was removed and transferred to another jurisdiction. ${ }^{60}$ Consequently, even though Anvil Mining was not formally accused, neither in the Military Court nor the Military High Court of Lubumbashi, both of them ruled that Anvil Mining was not implicated in human rights violations committed in Kilwa, with the aim of countering any other domestic initiative that could lead to the reopening of this trial at the national level.

Some scholars such as Clapham have argued that the reluctance of prosecuting MNCs in domestic courts by many AUMSs is mostly linked to the fear of losing them. ${ }^{61}$ For others, like Abiodun, MNCs and most of their host AUMSs share the same objective of exploiting the natural resources in these countries while the protection of human rights is relegated to the background. ${ }^{62}$ In this case, it is clear that the DRC should choose either the protection of its economic interests or the provision or real remedies to victims. Consequently, the outcome of the proceedings before the Military and the High Military courts of Lubumbashi showed that the priority was given to economic interests rather than the protection of human rights.

The main obstacle faced by victims in accessing effective remedies in Canada and Australia was the unwillingness of both countries to prosecute Anvil Mining for its wrongdoing abroad. Despite the fact that the Canadian judges were aware that this case was unfairly rejected by the DRC's jurisdictions, Canadian courts rejected it on the ground that victims were unable to prove their impossibility to access effective remedies in other domestic fora. In Australia, this case was not even brought before any court. After its dismissal by the DRC's courts, under the conditions described above, the Australian Federal Police abandoned its investigation against Anvil Mining. According to the BHRRC, the MNC's home countries frequently do not want to restrain their companies in carrying out their activities abroad, and this was the scenario in the Anvil Mining case. ${ }^{63}$

Although victims were unable to overcome the obstacles to access effective remedies in the domestic courts (as well as in other foreign domestic jurisdictions), in 2010 the same case was brought before the ACHPR where, in June 2017, the ACHPR condemned the $\mathrm{DRC}$ to pay USD 2.5 million to compensate the victims and obligated it to re-open criminal

58 MONUSCO Report, supra nt 35, 11.

59 McBeth, A, "Crushed by an Anvil: A case study of Responsibility for human rights in the Extractive Sector" 11(1) Yale Human Rights and Development Journal (2014) 144.

60 Global Witness, supra nt. 47, 11.

61 Clapham, A, Human rights obligations of Non-State Actors, (Oxford University Press, 2006) 238.

62 Abiodun, J O, Global commerce and human rights: Towards an African Legal Framework for corporate human rights responsibility and accountability, ( $\mathrm{PhD}$ thesis, University of the Witwatersrand, Johannesburg, South Africa, 2015) 93-94.

63 BHRRC, Corporate Legal Accountability, June 2012, at < business-humanrights.org/sites/default/files/ media/documents/corporate-legal-accountability-annual-briefing-final-20-jun-2012.pdf $>\quad$ (accessed 19 November 2017). 
investigations against the perpetrators of the human rights violations of Kilwa. ${ }^{64}$ Moreover, in the SERAC v. Nigeria case, the ACHPR previously held Nigeria to also be responsible for the degradation of the environment in Ogoni Land. In reality, however, these abuses were committed by Shell, a Dutch MNC. ${ }^{65}$ Even if in the two decisions the ACHPR was clearly influenced by the traditional view of international law, where violations can only be found against states and not private entities, the ACHPR was used to force member states to provide effective remedies to victims.

\section{B. The Talisman's Case of Sudan \\ i. Introduction}

Talisman Energy (known simply as Talisman) was one of the largest MNCs from Canada engaged in the exploitation, development, production, transportation, and marketing of crude oil and natural gas. ${ }^{66}$ This company operated in Sudan from August 1998 until March 2003. ${ }^{67}$ During the same period, Talisman sustained other activities in various parts of the world including the U.S. ${ }^{68}$ As of January 2016, Talisman Energy has acquired a new name and is now called Repsol Oil \& Gas Canada. ${ }^{69}$

The entry of Talisman into partnership with the Sudanese government in 1998 was highly criticised by different countries and many human rights organisations because Sudan was accused of using the oil revenue to finance the war during which many human rights violations were reported to be committed ${ }^{70}$ After the installation of Talisman in Sudan, the criticism did not cease. For example, in 2000, Canada, in which Talisman was incorporated, continued to denounce the use of the oil revenue by the government of Sudan in the exacerbation of the conflict in that country. ${ }^{71}$ Analysis of the criticism, which was addressed to Talisman, suggests that this company was likely to have been aware that its activities in Sudan would have negative impacts on the rights of the non-Muslim populations who were targeted by the Sudanese military and pro-government militias during the ongoing war.

This case illustrates how a collaboration between an MNC and its host AUMS in the violation of human rights constitutes a major obstacle to the victims' right to access effective remedies in national jurisdictions. It also reveals how similar AUMSs lack appropriate laws

64 African Commission, The Institute for Human Rights and Development in Africa (IHRDA) and other v. Democratic Republic of Congo, Communication 393/10, pp. 41-42, at <raid-uk.org/sites/default/files/african commission_decision_on_kilwa_2017.pdf> (accessed 19 November 2017).

65 Amao, O O, "The African Regional Human rights System and multinational Corporations: Strengthening the Host State Responsibility for control of Multinational Corporations," 12(5) International Journal for human rights (2008) 771.

66 Office of Fair Trade, Anticipated acquisition by Talisman Energy Resources Limited of Paladin Resources plc, 12 December 2005, at <assets.publishing.service.gov.uk/media/555de40640f0b666a20000e2/talisman.pdf> (accessed 19 November 2017).

67 Kobrin, S J, Multinational Enterprise, and public responsibility: The case of Talisman Energy and human rights in Sudan, (Cambridge University Press, 2005) 188-189.

68 US District Court for the Southern District of New York, The Presbyterian Church of Sudan V. Talisman Energy Inc. and the Republic of Sudan, Opinion 01 Civ. 9882(AGS), 19 March 2003, at $<$ law.justia.com/cases/federal/district-courts/FSupp2/244/289/2287736/> (accessed 7 November 2017).

69 Business guide, Canadian oil company Talisman Energy now has a new name, at <offshoreenergytoday.com/talisman-energy-has-a-new-name/> (accessed 19 November 2017).

70 Magdalena, B, Exploring Responsibility. Public and private in human Rights protection, (Lund University, 2005) 108.

71 Kobrin, supra nt 67, 191. 
to deal with the MNC's human rights abuses committed on their territories. Moreover, the present case also captures other barriers that these victims face in foreign domestic jurisdictions, such as diplomatic relations or political interference, that hinder their right of access to an effective remedy.

\section{ii. A Brief Description of the Facts}

As Talisman landed in Sudan during the civil war, it was necessary to first obtain security guarantees from the Sudanese government to be able to operate. For that purpose, in 1999 the Sudanese government re-grouped all MNCs which were engaged in oil exploitation in Sudan in what they called the Greater Nile Petroleum Operating Company (GOPC) where a security arrangement was concluded with them. ${ }^{72}$ Firstly, under the arrangement, the GOPC was requested to build the roads linking the military bases with the oil concession areas and to upgrade two airports that could be used by Sudanese soldiers within the oil exploitation areas. Secondly, the Sudanese government committed to open military garrisons around the oil exploitation fields. ${ }^{73}$ As argued by Kobrin, while Talisman was one of the MNCs within the GOPC, its huge funding and technical expertise were crucial for the success of that initiative. ${ }^{74}$ Later on it was reported that the facilities upgraded by the GOPC group, in which Talisman had a prominent role, were used by the Sudanese military forces and the pro-government militias in the perpetration of gross human rights abuses in Sudan. For instance, the Heglig, one of the airports upgraded by Talisman in its area of exploitation, was used by the Sudanese forces and the pro-government militias to carry out indiscriminate attacks against civilians. ${ }^{75}$ In its report of 2000 on the situation in Sudan, the Canadian Ministry of Foreign Affairs as well as Talisman itself confirmed the use of the Heglig airport by the Sudanese forces during the attacks against Christians and other non-Muslim people in Sudan. ${ }^{76}$ It was also alleged that the same airport was frequently used by the Sudanese military forces to refuel their aeroplanes during their operations in which numerous human rights abuses were committed. ${ }^{77}$

In legal terms, Talisman's responsibility in the alleged human rights abuses arises from its close co-operation with the Sudanese government in the killings of Christians and other non-Muslims of Sudan. This is why Talisman was accused in American courts of aiding and abetting the Sudanese security forces and the pro-government militias in the perpetration of human rights abuses in Sudan. Moreover, many observers agree that Talisman benefited from these violations because its oil activities expanded in that region during that period. ${ }^{78}$

72 Morrissey, J, "Presbyterian Church of Sudan v. Talisman Energy, Inc.: Aiding and abetting Liability under the Alien Tort Statute" 20 The Minnesota Journal of International Law, (2011) 147.

73 Ibid.

74 Kobrin, supra nt 67, 443.

75 Gagnon, G et al., Deconstructing engagement: Corporate self-regulation in conflicts zones, implication for human rights and Canadian Public Policy, Social Sciences and Humanities Research Council and the Law Commission of Canada, (January 2003), 26.

76 Morrissey, supra nt 72, 144.

77 Human Security in Sudan: The report of a Canadian Assessment Mission, Canadian Ministry of Foreign Affairs, Ottawa, (January 2000),15, at <ecosonline.org/reports/2000/Human\%20Security\%20in\%20Sudan.pdf> (accessed 19 November 2017).

78 Milbank et al., Litigation: No liability for violation of international law unless aid was purposeful, second circuit rules in case brought under Alien Tort Statute, (October 2009), 1, at <milbank.com/images/content/6/9/ 699/101309-Presbyterian-Church-of-Sudan-v-Talisman-Energy-Inc.pdf> (accessed 19 November 2017). 


\section{iii. The Victims' Endeavours to Access Effective Remedies}

Given the nature of the acts which were committed and the direct involvement of the Sudanese government in their perpetration, victims were afraid to seek remedies in domestic courts. For that reason, on 8 November 2001, the Presbyterian Church of Sudan together with other residents from Southern Sudan - a region where Talisman was operating - filed a case against Talisman in the New York District Court. ${ }^{79}$ The plaintiffs accused Talisman to have collaborated with the Muslim government of Sudan in violating the rights of Christians and other non-Muslim people around its areas of operation. ${ }^{80}$ In concrete terms, Talisman was accused of aiding and abetting the Sudanese government in 'the killing, forcible displacement, war crimes, confiscation and destruction of property, kidnapping, rapes, and enslavement' of Christians and other non-Muslim people in the South Sudanese region; acts which together were qualified as genocide.$^{81}$ This case was introduced in the US Court under the Alien Tort Claim Act (ATCA), providing US federal courts with powers to deal with cases of human rights abuses committed by MNCs abroad irrespective of the nationality of the victims or the MNCs in question. ${ }^{82}$

Before ruling on the merits of such cases, in practice, the U.S. courts must first weigh the facts against the forum non conveniens doctrine. This doctrine allows US courts to dismiss a case if the defendant is able to prove the existence of another appropriate forum to deal with the case and to take into account other public or private interests, such as the possibilities of both parties to access evidence. ${ }^{83}$ In the New York District Court's decision of March 2003, the judges initially allowed the case to proceed. In the decision, the judge first questioned the independence of the Sudanese courts because the Sudanese forces and the pro-government militias were alleged to be the direct perpetrators of these abuses. ${ }^{84}$ Secondly, the judge held that the application of Sharia law to victims who were largely nonMuslims was unfair. ${ }^{85}$ Moreover, the Court found that the Canadian courts were not the appropriate forum to deal with the case because Canada lacked proper legislation to deal with the situation at hand and therefore decided to dismiss Talisman's defence ${ }^{86}$ However, this decision has been strongly contested by the Canadian and American governments, in such way that their opinions have influenced, in one way or another, the final outcome of this case in the US courts. According to Seck, Canada intervened twice to support Talisman before the US courts. ${ }^{87}$ Likewise, when this case was ongoing in the New York District

79 Kobrin, supra nt 67, 450.

80 US District Court for the Southern District of New York, The Presbyterian Church of Sudan V. Talisman Energy Inc. and the Republic of Sudan, Opinion 01 Civ. 9882(AGS), 19 March 2003, at <law.justia.com/cases/federal/district-courts/FSupp2/244/289/2287736/> (accessed 7 November 2017).

81 US District Court for the Southern District of New York, The Presbyterian Church of Sudan V. Talisman Energy Inc. and the Republic of Sudan, Opinion 01 Civ. 9882(AGS), 19 March 2003, at $<$ law.justia.com/cases/federal/district-courts/FSupp2/244/289/2287736/> (accessed 7 November 2017).

82 Par, N S et al., Beyond impunity: Strengthening the legal accountability of transnational corporations for human rights abuses, (Hertie School of Governance, 2009) 18.

83 Jägers, N M C P, Corporate human rights obligations: in search of accountability, (Intersentia, 2002) 196-197.

84 Mongelard, E, "Corporate civil liability for violations of international humanitarian law", 88(865) International Review of the Red Cross (2006) 690.

85 Ibid.

86 Ibid.

87 Seck, S L, "Home state responsibility and local communities: The Case of Global Mining", 11(1) Yale human rights and development Journal (2014) 7. 
Court, the American government sent a letter to that court with a diplomatic correspondence from Canada that contained an attachment explaining that a continuation of this case in the US will have an impact on the diplomatic relations between the two countries. In the same letter, the US authorities also advised the judges of the New York District Court to narrow the application of the ATCA. ${ }^{88}$ It appears that the Canadian and US governments were not concerned about the redress of the abuses which were alleged against Talisman, rather than the pursuit of this case in US courts. The reluctance of both countries to provide effective remedies to victims of these abuses is easily observed through the efforts deployed by both, the Canadian and the US government, to obstruct the victims' right to access effective remedies in US courts. Consequently, in 2006, just four months before the trial of this case on its merits, a summary judgement was issued by the same New York District Court in favour of Talisman in which the court ruled that Talisman did not act with 'an intent' of supporting the Sudanese government in abusing human rights. ${ }^{89}$

In February 2007, representatives of victims appealed against that decision but without success. In its decision of October 2009, the Appellate Court for the $2^{\text {nd }}$ Circuit upheld the decision of the lower court in which the Judge stressed again that Talisman did not act 'purposefully' to support the Sudanese government in the perpetration of human rights abuses. ${ }^{90}$ Yet in the same decision, the $2^{\text {nd }}$ circuit Appellate Court acknowledged that victims managed to prove that Sudan has used Talisman's facilities to commit human rights violations. ${ }^{91}$ Trying to reverse the decision, representatives of victims filed a petition to the US Supreme Court. Another organisation called Earth Rights International also submitted amicus curiae to the same court. The complainants were requesting the Supreme Court to hear the appeal against the ruling from the Court of Appeal. ${ }^{22}$ But in October 2010, the U.S. Supreme Court rejected these two requests. ${ }^{93}$ As a result, Talisman was discharged from its responsibility in human rights violations in which the company is alleged to have played a big role.

\section{iv. Obstacles Met by the Victims to Access Effective Remedies}

The facts in the Talisman case reveal two major difficulties encountered by victims to access effective remedies in the Sudanese courts. First, victims were physically threatened. Given the role played by the Sudanese military and the pro-government militias in the abuses which were alleged against Talisman and the nature of the conflict (ethnic and religious conflict), victims were unable to have their case heard in the Sudanese courts. The collusion between government forces and MNCs in the perpetration of human rights abuses is not unique to Sudan. The same scenario is often alleged in many AUMSs where their victims become unable to bring cases in domestic courts for fear of their physical safety. Second, the independence of the Sudanese justice system, as well as the nature of the applicable law in the Sudanese courts, was questionable since they apply Sharia Law even though all victims

88 Stephens, B, Judicial deference and the unreasonable views of the Bush administration, 798, at <brooklaw.edu/ /media/645D4523327F475EA08E0A88BEA513CA.pdf> (accessed 7 November 2017).

89 Davis, J, Justice across boarders: The Straggle for human rights in U.S. Courts, (Cambridge University Press, 2008) 83.

90 BHRRC, Talisman lawsuit (re Sudan), at <business-humanrights.org/en/talisman-lawsuit-re-sudan> (accessed 7 November 2017).

91 Milbank et al., supra nt 78, 2.

92 BHRRC, Talisman lawsuit (re Sudan), supra nt 90.

93 Ibid. 
were non-Muslims. It appears inconceivable to pretend to access effective remedies under the rules of a religion to which you do not belong yourself.

The main obstacle faced by victims to access effective remedies in the US courts was the political interference by both, Canada and the US. The introduction of this case before the New York District Court has raised many reactions from both countries to oppose its continuation within US jurisdiction, reactions which have led to its rejection in the US. Victims could not bring their case in Canadian courts due to the fact that Canada had played an important role in its rejection by the American courts. But legally speaking, the US courts used the concept of 'proof of intent' which, in reality, is not easy to demonstrate in such cases. As argued by de Jonge, in these cases the proof of intent is more complicated than the proof of knowledge. ${ }^{94}$ In other words, this new standard introduced by US courts in cases implicating MNCs and human rights constitutes an additional obstacle for victims of the MNCs' human rights abuses from the AUMSs who would like to seek remedies in US courts.

\section{The Trafigura Case of Ivory Coast \\ i. Introduction}

Trafigura is an MNC from the Netherlands which has its headquarters in Amsterdam. The company also has many other offices and subsidiaries in different countries worldwide. ${ }^{95}$ Trafigura is among the world's largest MNCs trading oil, metals and minerals. ${ }^{96}$ The incident at the centre of this case took place on the night of 19 August 2006 when a ship charted by a Trafigura office in London, called Probo Koala, dumped toxic wastes in Abidjan, the capital city of Ivory Coast. ${ }^{97}$ As this ship belonged to Trafigura's London office, presumably, the orders to dump these toxic wastes in Abidjan emanated from the same office.

The present case illustrates how MNCs use their power to undermine the victims' right of access to effective remedies in domestic jurisdictions of the AUMSs. It also reveals that the Ivory Coast, like many other AUMSs, lacks appropriate laws to deal with human rights abused committed by MNCs on their territories. Furthermore, the case also demonstrates how the victims' chance to access effective remedies in other foreign domestic jurisdiction is limited.

\section{ii. A Brief Description of the Facts}

Before heading to Abidjan, the Probo Koala ship tried first to dispose of these toxic wastes legally in some European ports but without success. For example, in July 2006, the ship concluded an agreement with the Amsterdam port to dispose of the toxic wastes in

94 De Jong, A, Transnational corporations and international law: Accountability in the Global Business Environment, Edward Elgard, London/ UK and Northampton USA (2011) 105.

95 Trafigura Ltd, Annual report of 2015, 30 September 2015, 2, at <trafigura.com/media/3321/2015-trafiguraannual-report.pdf $>$ (accessed 8 November 2017).

$96 \quad I d, 4-5$.

97 Human Rights Council Report, Rapport of the Special Rapporteur on the adverse effects of the movement and dumping of Toxic and dangerous products and wastes on the enjoyment of human rights: Mission to Cote d'Ivoire (4 to 8 August 2008) and the Netherlands (26 to 28 November 2008) of the 3rd September 2008, Report n0 A/HRC/12/26/Add.2, 8 . 
question. ${ }^{98}$ After its arrival in Amsterdam, a company which was sub-contracted by the Amsterdam port to carry out this job discovered that the toxicity of the waste was very high and decided to increase the price of their treatment. ${ }^{99}$ As most MNCs appear to be more concerned about their bottom line, Trafigura did not agree with the port of Amsterdam on the new proposed price and decided to conclude a new agreement with Tommy Ltd., a newly created company in Ivory Coast, which had no prior experience in such matters. ${ }^{100}$ It is important to highlight that this Ivorian company was only created ten days before the arrival of the Probo Koala ship in Abidjan, ${ }^{101}$ a fact that might suggest that this company was created for that purpose. It is also evident that, before the dumping of these wastes in Abidjan, Trafigura was fully aware of the level of their toxicity and that they could have harmful effects on human lives and the environment.

According to a report by Amnesty International, the toxic wastes in question were dispersed 'in at least 18 sites near the inhabited and business places in Abidjan during the night of 19 August 2006. ${ }^{102}$ The report of the UN Human Rights Council of 2008 also alleged that other similar wastes were dumped later during the night of 14 September 2006 in Abidjan. ${ }^{103}$ Immediately after the occurrence of the incident, people who lived around the sites where these wastes were dumped caught different diseases. ${ }^{104}$ Different reports alleged that 15 people died, 69 persons were hospitalised and as many as 108,000 went through medical consultations. ${ }^{105}$ According to Jägers, 'the Trafigura ship incident of Abidjan has resulted in tragic consequences for human lives and environment. ${ }^{106}$ More specifically, the rights which were violated include the right to life, the right to health, the right to information, the right to food and wellbeing, rights to a satisfactory environment, the right to private life and the right to development. All the listed rights are recognised under different international and regional human rights instruments including the ACHPR to which the Ivory Coast is a party.

\section{iii. The Victims' Endeavours to Access Effective Remedies}

Few days after the Probo Koala incident of Abidjan, the Ivorian state prosecutor opened a criminal investigation against those who were suspected to be involved in these outrageous acts and arrested some of them. ${ }^{107}$ Among those arrested were three high officials of Trafigura who were present in Ivory Coast and representatives of the Ivorian company

98 Chuakan, E, The Probo Koala incident in Abidjan Cote d'Ivoire: A critique of the Basel Convention compliance mechanism, Secretariat of the Basel Convention, United Nations Environment Programme, (Geneva, 2016) 352-353.

99 Ibid.

${ }^{100}$ Cox, G, "The Trafigura case and the system of prior information consent under the Basel Convention - A broken system", 3 Law Development and Environment Journal (2010) 274.

${ }^{101}$ Environmental Justice Organizations Liabilities and Trade (EJLT), The Trafigura case, Fact sheet 045, 05 August 2015, at <ejolt.org/wordpress/wp-content/uploads/2015/.../FS-45.pdf> (accessed 8 November 2017).

102 Amnesty International, supra nt 28, 97.

${ }^{103}$ Human Rights Council, supra nt 97, 8.

${ }^{104} I d, 9$.

105 Ibid.

106 Jägers, N M C P and van der Heijden, M J C, "Corporate Human Rights Violations: The feasibility of civil recourse in the Netherlands" 33 Brooklyn Journal of International Law (2008) at $<$ pure.uvt.nl/ws/files/.../bjil33iii_Jagers.pdf> (accessed 8 November 2017).

107 Amnesty International, supra nt 28, 101. 
Tommy Ltd. ${ }^{108}$ As a legal person, however, Trafigura was not a subject of the investigation as Ivorian law does not provide for criminal liability of legal persons. ${ }^{109}$ However, surprisingly, when this case was ongoing before the Ivorian courts the government of the Ivory Coast entered into negotiations with the Trafigura Group without any prior consultation with victims. These negotiations resulted in an out-of-court settlement in February 2017. ${ }^{110}$ In this agreement, the Trafigura Group agreed to pay USD 198 million for the compensation of the victims but against the release of their employees who were arrested. Under the same agreement, Ivory Coast also agreed to waive any other action against the Trafigura Group in domestic courts in relation to that incident. ${ }^{111}$ However, Trafigura has continued to deny any responsibility for the abuses in question. ${ }^{112}$ This agreement has negatively affected the victims' rights of access to effective remedies in domestic jurisdictions in many ways. First, as mentioned earlier, the agreement was signed without any prior consultation with the victims which means that those who signed it did not have enough information about what should be redressed. Secondly, victims who have not been compensated or those who received insufficient compensation cannot bring their cases in domestic courts in Ivory Coast. Moreover, as the above-mentioned agreement concerned civil cases only, this agreement constituted a barrier for victims who would like to initiate criminal proceedings against Trafigura group in Ivory Coast. But in March 2008, the Court of Appeal in Abidjan dismissed the complainants' request by ruling that the evidence to proceed with their case was lacking. ${ }^{113}$

After exhausting all domestic remedies in Ivory Coast, some victims filed their case before the English courts due to the fact that, as mentioned before, the Probo Koala ship was charted by the Trafigura London office. This case was introduced before the London High Court in November 2006 by a number of victims who were estimated to be around 30,000. ${ }^{114}$ After three years of proceedings, in September 2009, another out-of-court agreement was concluded between the parties to the case. Under this new agreement, Trafigura accepted to pay GBP 1,000 to each of the claimants for compensation. ${ }^{115}$ But again, this agreement was achieved with an obligation for victims to release a declaration stating that the toxic waste dumped in the streets of Abidjan by the Probo Koala ship did not have the potential to cause any serious injury or death. ${ }^{116}$

108 Ibid.

109 Green Peace and Amnesty International, The toxic truth about a company called Trafigura, A ship called Probo Koala, and the dumping of the toxic waste in Cote d'Ivoire, September 2012, 130, at <amnestyusa.org/sites/default/files/afr310022012eng.pdf> (accessed 19 November 2017).

${ }^{110}$ Human Rights Council Report, supra nt 97, 15.

111 Ibid.

${ }^{112}$ Gwam, CU, "Human Rights implications of illicit toxic waste dumping from developed countries including the U.S.A, especially Texas to Africa, In particular Nigeria", 38 Thurgood Marshall Law Review (2014) at <tmlawreview.org/assets/uploads/2014/07/9-Gwam1.pdf> (accessed 19 November 2017).

113 Ibid.

114 BHRRC, Corporate legal accountability, Annual brief, June 2012, 5, at < business-humanrights.org/sites/ default/files/media/documents/corporate-legal-accountability-annual-briefing-final-20-jun-2012.pdf> (accessed 19 November 2017).

115 Environmental Justice Organizations Liabilities and Trade (EJOLT), The Trafigura case, Fact sheet 045, 05 August 2015, at <ejolt.org/wordpress/wp-content/uploads/2015/.../FS-45.pdf> (accessed 8 November 2017).

116 Ibid. 
In addition to the proceedings which took place in the UK in 2008, the Dutch Prosecutor had also opened a criminal case against the Trafigura Group and some of its employees. The director of the Amsterdam Port Service (APS), where the Probo Koala ship departed to Abidjan from, and the Municipality of Amsterdam were also concerned by these investigations. ${ }^{117}$ But before the Dutch courts, the Trafigura Group and its co-accused were only accused for their illegal acts which took place in the Netherlands, not in the Ivory Coast. Trafigura was charged with illegal exportation of toxic waste from the Netherlands to Africa; an act which infringes the European regulations on the shipment of such waste. Other co-accused were considered as accomplices in that operation with different levels of liability. ${ }^{118}$ The proceedings in this case took four years in which the Trafigura Group was sentenced to pay EUR one million and the company's employees were condemned to various suspended sentences of imprisonment. ${ }^{119}$ The cases of other co-accused, like the Director of the APS and the Amsterdam Municipality, were declared inadmissible under Dutch law. ${ }^{120}$

\section{iv. Obstacles Met by the Victims to Access Effective Remedies}

The analysis of the facts in this case demonstrates that two major obstacles have obstructed victims' access to effective remedies in domestic jurisdictions. Firstly, the economic power of the Trafigura Group. While the evidence revealed that the crew of the Probo Koala knew beforehand that the waste was highly toxic, to avoid its responsibility the Trafigura group negotiated an agreement with the Ivorian government where neither party consulted the victims before or during these negotiations. The outcome of this agreement resulted in a denial of the victims' right to access effective remedies. The Trafigura Group paid a certain amount of money - officially for the compensation of the victims - against the release of its employees who were arrested as well as the renunciation and the prohibition of any other action against this MNC in Ivory Coast in relation to the same case. Given the large number of victims and the violations which occurred during the Probo Koala incident in Abidjan, even if the Ivorian government should have used the proceeds of the settlement to compensate the victims, this amount would be insufficient. Secondly, the Ivorian justice system lacked an applicable law to criminally prosecute the Trafigura Group as a private legal entity which is a common barrier in many AUMSs.

In regard to the case which was introduced in the UK, first, this case was again interrupted by another out-of-court settlement in which not all victims were represented. Secondly, according to the Council of Europe, 'a remedy is only effective if it is available and sufficient. ${ }^{121}$ Given the number of victims, it is normal that the harm suffered by each one be different. But under that agreement, every person who was represented was entitled to receive GBP 1,000, which probably was insufficient for some of them. Third, although UK officials were pressured by different organisations to commence criminal proceedings

117 Green Peace and Amnesty International, supra nt 109, 155.

118 Ibid.

119 Jesse, K D and Verschuuren, J, "Country report: The Netherlands", 1 The IUSN Academy for environmental law journal (2011), at <pure.uvt.nl/ws/files/1315290/Verschuuren_Country_Report_The_Netherlands_ 110303_publishers_immediately.pdf> (accessed 19 November 2017).

${ }^{120}$ Ibid.

${ }^{121}$ Council of Europe, Guide to good practice in respect of domestic remedies, adopted on 18 September 2013, at $<$ coe.int/t/dghl/standardsetting/cddh/CDDH-DOCUMENTS/GuideBonnesPratiques-FINAL-EN.pdf> (accessed 8 November 2017). 
against the Trafigura Group, they decided not to do so based on what they called 'a lack of financial resources to finance complex investigations. ${ }^{, 122}$ This also means that victims lacked financial resources to begin criminal investigations against the Trafigura Group in the UK because they were not entitled to benefit from the legal aid fund which is provided by the UK government. The lack of financial resources by victims to pay advocates and follow the proceedings in their cases in foreign jurisdictions is a general obstacle victims of human rights abuses committed by MNCs in the AUMSs face. As to Amnesty International, in the context of the MNCs' human rights abuses, an effective remedy includes both measures to redress the harm suffered by victims as well as actions taken by States to hold MNCs accountable in their justice systems. ${ }^{123}$ This means that the compensation of victims does not preclude criminal charges against MNCs for their human rights violations. In this case, it has to be acknowledged that Trafigura exerted some effort to compensate the victims but no criminal investigation took place, either in Ivory Coast or in the UK.

With regard to what happened in the Netherlands, the victims' case was declared to be inadmissible before the Dutch courts. This is due to the fact that Trafigura was only prosecuted for its wrongdoing in the Netherlands but not in the Ivory Coast. This decision was grounded on what the judge referred to as 'complexity of investigations which required a close collaboration with Ivory Coast. ${ }^{124}$ The reason given by the Dutch court in this case is somewhat strange because it is not common for a court to dismiss a case because of the complexity of its investigations. But on the other hand, this could simply be interpreted as an unwillingness of the Dutch courts to prosecute Trafigura for its human rights misconducts committed in Ivory Coast.

\section{Access to Justice for Victims of the MNCs' Human Rights Misconducts in the AUMSs: A Challenge to the 'African Solutions to Africa's Problems' Concept}

\section{A. Introduction}

Historically, the African solutions to Africa's problems concept originate from Pan-African ideals in the 1960s. But according to Kasaija, its current resurgence resulted from the collapse of the State in Somalia in the 1990s and the failure of the international community to deal with the genocide of the Tutsi in Rwanda of $1994 .{ }^{125}$ In its second facet, the same concept also has its source in what some African leaders call a foreign interference in the internal affairs of African states by Western countries. ${ }^{126}$ This means that in its purely political aspect, this concept is perceived as a tool to fight against neo-colonialism in African countries.

122 The Guardian, "UK authorities' lack resources' to investigate Trafigura over toxic waste", 23 July 2015, at $<$ theguardian.com/world/2015/jul/23/uk-authorities-lack-resources-to-investigate-trafigura-over-toxicwaste $>$ (accessed 19 November 2017).

123 Amnesty International, supra nt 28, 29.

${ }^{124}$ Environmental Justice Organizations Liabilities and Trade (EJOLT), supra nt 115, 8.

125 African Centre for Constructive Resolution of Disputes, Kasaija, PA, The African Union's notion of African Solutions to Africa's problem' and the crises in Cote d'Ivoire (2010-2011) and Libya (2011), 11 June 2012.

${ }^{126}$ Ferim, V, African solutions to African Problems: The Fault line in conflict Resolution in Africa, at <academia.edu/5924312/African_Solutions_to_African_Problems> (accessed 19 November 2017) 2. 


\section{B. The Content of the Concept of African Solutions to Africa's Problems}

The concept of African solutions to African problems advocates that, instead of waiting or asking for support from other continents or any other aid from outside Africa, Africans should first be able to deal with the problems arising on their continent. ${ }^{127}$ Some scholars argue that this concept implies a 'sense of self-reliance, responsibility, ownership and indigeneity' of solutions to all problems that affect or may African communities. ${ }^{128}$ In relation to the non-redress of the MNCs' human rights abuses committed in the AUMSs this philosophy presupposes that African leaders should not passively watch the development of such phenomena on the continent instead of putting in place adequate and purely African measures to address it.

The 'African solutions to African problems' philosophy is currently applied to a wide range of issues in Africa, but mostly in the area of promoting peace and security. Article 4(f) of the AU Act of 2000 provides the AU with powers to intervene in member states in cases of gross human rights abuses, namely 'war crimes, genocide and crimes against humanity. ${ }^{129}$ This is why today many troops from the AUMSs are engaged in various peacekeeping missions across the African continent. For example, contingents from different AUMSs are currently involved in peacekeeping operations in Mali, the Central African Republic, Somalia and South Sudan. The same understanding of the African leaders of this concept and its application to a wide range of issues on the continent should also motivate them to seek solutions to the question of access to effective remedies for victims of the MNCs' human rights abuses that are often committed in the AUMSs.

\section{The Non-Redress of the MNCs' Human Rights abuses in the AUMSs vis-à-vis the African Solutions to African Problems Concept}

The experience from the case studies discussed above suggests that most of the MNCs' human rights abuses committed in the AUMS remain unpunished and the AU regional and sub-regional mechanisms have done nothing significant to solve this issue. This situation reflects a lack of confidence in national, regional and sub-regional judicial and quasi-judicial institutions. More specifically, the reluctance of the AU regional and sub-regional mechanisms to solve this problem seems to be in contradiction with the philosophy contained in the concept of African solutions to African problems. In fact, the AU, as a regional organisation, as well as different sub-Regional Economic Communities (RECs), can play a vital role in addressing this situation.

At the regional level, the system of human rights protection is centred around the African Charter of $1986,{ }^{130}$ which has quite similar provisions to those of many other human rights instruments. ${ }^{131}$ The Charter obliges member states to provide effective remedies for victims of human rights abuses committed on their territories; most of which are reported to

${ }^{127}$ Adar, K G et al., The State of Africa: Parameters and legacies of governance and issue areas, (Africa Institute of South Africa, Pretoria, 2010) 115.

${ }^{128}$ Laurie, N, African solutions to African problems, October 2013, at <up.ac.za/media/shared/ Legacy/sitefiles/file/46/1322/17295/welttrends92themanathansdafrikaafrikanischeunionsicherheitspolitik diplomatie.pdf> (accessed 10 November 2017).

129 The Constitutive Act of the African Union adopted in Lomé, Togo, on the 11th July, 2000, (2000).

130 African Union, African Charter on Human and People's Rights, (1986) UNTS 218.

${ }^{131}$ Nmehielle, V O, "Development of the African Human Rights System in the Last Decade", Human Rights brief 11, n. 3, 2004, at <digitalcommons.wcl.american.edu/cgi/viewcontent.cgi?article=1368\&conte> (accessed 10 November 2017). 
be committed by MNCs in violation of the Charter's provisions. For instance, on the African continent, many reports frequently allege that MNCs fail to meet the requirement of maintaining a satisfactory environment in the oil extraction industry; such acts infringe Article 24 of the African Charter. ${ }^{132}$

To enforce the provisions of the African Charter, as well as other relevant human rights instruments adopted under the auspices of the African regional organisation (OAU/AU), the ACHPR was established under the same instrument. ${ }^{133}$ As mentioned earlier, the ACHPR has already tried a number of cases of human rights violations involving MNCs which were committed in the AUMS. According to some scholars, nowadays, states are gradually losing their monopoly on being seen as the only subjects of international law as MNCs have also become duty bearers in regard to human rights issues. ${ }^{134}$ As legal entities, today MNCs have duties and responsibilities under the African Charter as well as under other human rights instruments.

To supplement the shortcomings of the ACHPR in the fulfilment of its mandate of protecting human rights across the AUMS, an African Court on Human and Peoples' Rights (ACtHPR) was created. ${ }^{135}$ The ACtHPR was created by a protocol that was adopted in 1998 and which entered into force in 2004. ${ }^{136}$ First, this instrument commits the AU to the principles of freedom, equality, justice, peace and dignity as well as to the fundamental rights and duties contained in different human rights instruments and declarations adopted by the AU and other international organisations. ${ }^{137}$ It also vests the ACtHPR with the mandate to enforce the provisions of the African Charter, the protocol itself and other human rights instruments ratified by the concerned AUMS. ${ }^{138}$ Moreover, in May 2012, the AU adopted a protocol providing the court with powers to rule on international crimes committed within member states without any exception. ${ }^{139}$ Additionally, Article $46 \mathrm{C}$ of the Protocol to the Statute of the ACtHPR (27 June 2014) provides the ACtHPR with powers to deal directly with the MNCs' criminal liabilities in case they commit human rights abuses in member States. ${ }^{140}$

At the sub-regional levels, most African Regional Economic Communities (RECs) have also put mechanisms in place to protect human rights in their respective regions. Understandably, the initial mandates of these RECs are to improve their trade and other

${ }^{132}$ The South African Institute for the Advanced Constitutional, Public Human Rights \& International Law, The State Duty to Protect, Corporate Obligations and Extra-territorial Application In the African Regional Human Rights System, (Johannesburg, 2010) 12.

133 Article 30, African Union, African Charter on Human and People's Rights, (1986) UNTS 218.

${ }^{134}$ Slawotsky, J, "Corporate liability for violating international law under The Alien Tort Statute: The corporation through the lens of globalization and privatization", 2 International Review of Law, 2013, 15.

${ }^{135}$ Hansungule, M, African Courts and the African Commission on Human and Peoples' Rights, at $<$ kas.de/upload/auslandshomepages/namibia/Human_Rights_in_Africa/8_Hansungule.pdf> (accessed 19 November 2017) 151-152.

136 African Union, Protocol to the African Charter on Human and People's Rights on the establishment of an African Court on Human and People's Rights (2004).

137 Ibid.

${ }^{138}$ Id, Article 3.

139 Protocol on the amendments to the protocol on the African Court of Justice and Human Rights, adopted in Addis Ababa, Ethiopia on 15 May 2012.

140 The Protocol on the Statute of the ACtJHR of the $27^{\text {th }}$ June 2014. 
economic relations. ${ }^{141}$ However, the RECs have gradually acknowledged the reality that their economic goals cannot be achieved without integrating respect for human rights into their activities. ${ }^{142}$ This is why most of them integrated human rights provisions in their constituent treaties and their member states are parties to other human rights instruments. ${ }^{143}$ RECs are recognised by the AU under the Abuja Treaty of 3 June $1991 .{ }^{144}$ Article 3(h) of this Treaty bases the pursuit of Africa's economic integration on the principles of 'recognition, promotion and protection of human and peoples' rights' in accordance with the provisions of the African Charter, accountability and economic justice. ${ }^{145}$ Its Article 7(e) also gives powers to these RECs for creating their own Courts of Justice (CJ). ${ }^{146}$ Currently, these CJs of different RECs have similar jurisdiction over human rights issues committed in their respective regions as the ACtJHPR. ${ }^{147}$

Given the legal frameworks and mandates and some few good examples from the AU regional and sub-regional mechanisms, these institutions have potentialities that can be exploited to correct the shortcomings of their member states in proving effective remedies for victims of the MNCs' human rights abuses. However, the case studies discussed earlier in this paper have revealed that the non-redress of such abuses is a prevalent phenomenon on the African continent and the AU regional and sub-regional mechanisms remain virtually unused by victims. The same case studies have also exhibited that those victims who decide to seek remedies in foreign fora outside the African continent do not get any support from their home countries. Consequently, victims of the MNCs' wrongdoings committed in the AUMS seem to be left on their own in their quest for remedies, either in domestic courts or in other fora outside the African continent, a fact which seems to contradict the philosophy behind the concept of African solutions to African problems.

\section{Conclusion}

The right to access an effective remedy for victims of human rights violations is an internationally recognised right under international and regional instruments of human rights, regardless of whether their perpetrator is an individual or a legal entity such as an MNC. These instruments include measures to ensure procedural fairness to victims, whether by a court or any other competent body or mechanism, as well as the outcome of such proceedings including the relief afforded to victims. But nowadays, there are many MNCs operating in the AUMSs which are accused of being involved in human rights abuses and their victims face many obstacles to access effective remedies.

Through three selected case studies, the present article attempted to investigate and analyse what obstacles victims face, either in domestic jurisdictions, before the MNC's home

141 Jibril, A A, "The admissibility of Subregional Court's decisions before the African Commission or African Court", 6(2) Mizan Law Review (2012) 242.

142 Ibid.

${ }^{143}$ Rupell, O C, "Regional Economic Communities and Human Rights in East and Southern Africa", at $<$ kas.de/upload/auslandshomepages/namibia/Human_Rights_in_Africa/9_Ruppel.pdf> (accessed 10 November 2017) 277-279.

144 African Economic Community, Treaty Establishing the African Economic Community, Adopted in AbujaNigeria on $3^{\text {rd }}$ June 1991 and entered into force on 12 May 1994.

145 Ibid.

${ }^{146}$ Ibid.

${ }^{147}$ Vicente, DM, Towards a Universal Justice? Putting international Courts and Jurisdictions into perspective, (Brill Publishing, 2014) 108. 
jurisdiction or in other foreign jurisdictions. The selected cases are the Anvil Mining case of the Democratic Republic of Congo, the Talisman case of Sudan, and the Trafigura case of Ivory Coast. In this paper, two major points are underlined, the types of legal remedies used by victims and the obstacles they faced in each step of the procedure, either in their home countries or in other fora outside the African continent.

The analysis of the facts in these cases demonstrates that, in the Anvil Mining case of the DRC and the Trafigura case of Ivory Coast, both started in domestic jurisdictions and ended up in the MNCs' home jurisdictions. Moreover, two out-of-court settlements interrupted the Trafigura case's proceedings; one took place in Ivory Coast and the other in England. Regarding the Talisman case, this case started and ended in the US courts because victims were unable to introduce their case in the Sudanese courts. This was due to the fact that all the violations alleged against Talisman were directly committed by the Sudanese security forces and pro-government militias, meaning that victims feared for their physical safety. Sudan lacked an appropriate law that could be applied in this case because the Sudanese courts apply Sharia law even though all victims were non-Muslims.

The outcome of the proceedings in all three cases, either in the victims' home courts or in foreign domestic fora has resulted in a denial of the victims' right to access real and effective remedies. The discussions and analysis in these cases proved also that a reliance on the MNCs' home courts or on any other forum, is of a limited value because victims face other obstacles there.

The main obstacles faced by victims in the Anvil Mining case of the DRC included many dysfunctions and irregularities within the DRC's justice system. For example, the victims' difficulties in accessing their lawyers and the lack of co-operation with military officials, political interference within the justice system and the threat and intimidation of victims and their supporters. Whereas in the Trafigura case of Ivory Coast the power influence of Trafigura in conjunction with the lack of an appropriate law in the Ivorian justice system to prosecute legal entities undermined the victims' rights to access effective remedies in the Ivory Coast. These obstacles are not only present in the justice systems of the DRC and the Ivory Coast, but they also exist in many other AUMSs.

Among the major obstacles faced by victims in foreign jurisdictions are the unwillingness of the MNCs' home countries to prosecute them for their human rights abuses committed abroad, political interference, the possible diplomatic fallout between fora of prosecutions and home states of MNCs, the lack of financial resources by victims to commence and follow their cases abroad as well as the difficulties in conducting investigations and limited access to evidence. Considering all these obstacles faced by victims in their quest for remedies, either in domestic or foreign courts, the paper suggests that there is an urgent need for African regional and sub-regional solutions to fill this gap.

Discussions and analysis in this paper revealed, on the one hand, that the lack of redress of human rights abuses that are often committed by MNCs in the AUMS is a common phenomenon on the continent and African leaders contemplate its development passively. On the other hand, although African communities are those who are more affected by this issue, there are mechanisms at the AU regional and sub-regional levels that can be used to correct the shortcomings of national systems from member states in providing effective remedies for victims. Unfortunately, as it was revealed by the case studies, victims of these abuses from the African continent are somehow left in the hands of the MNCs in 
The Status of Access to Effective Remedies by Victims of Human Rights Violations 277

Committed by Multinational Corporations in the African Union Member States

question, a reality which seems to be in contradiction with the philosophy behind the concept of African solutions to African problems.

\author{
www.grojil.org
}

